\title{
Caladium Cultivars Developed at the University of Florida/IFAS ${ }^{1}$
}

\section{Z. Deng and B.K. Harbaugh ${ }^{2}$}

Caladiums (Caladium $\mathrm{x}$ hortulanum) are popular ornamental plants. They are members of the Araceae family and originated in the New World tropics. These plants display a wide diversity of leaf shapes, colors, and color or vein patterns that is rarely found in other cultivated plant species. Their colorful leaves rival many flowers, and the plants grow well in summer heat and shady conditions.

Potted and landscape caladium plants are grown from tubers (they are often called bulbs). Most of the tubers used throughout the world are produced in Florida. Large-scale commercial production of caladium tubers in Florida can be traced back to the 1930s. Cultivars used by the industry were bred from the 1860 s to 1920 s by several horticulturists and hobbyists in Florida, Brazil, England and France. Until the release of new cultivars from the University of Florida breeding program in 1988, the industry had been without new caladium introductions since the 1950s.

The University of Florida's Institute of Food and Agricultural Sciences (UF/IFAS) initiated a caladium breeding program in 1976 at the Gulf Coast Research and Education Center in Bradenton, Florida. So far, this has been the only major organized caladium breeding program in the world. The program's main objectives were to develop new cultivars that: 1) can produce many bright colorful leaves and a high yield of good quality tubers; and 2) have short, sturdy petioles and multi-eyed tubers that can result in increased early leaf production and improved leaf display. Additional goals of this program included the following: 1) to improve the aesthetic values and performance of caladium plants in containers and landscapes; 2) to eliminate the costly labor associated with tuber de-eyeing; and 3) to improve tuber and plant productivity and profitability.

Hybridizations among commercial caladium cultivars followed by rigorous selection and multiple year evaluations on muck and sandy soils have resulted in the release of 13 new cultivars (Table 1). These cultivars possess a diverse range of leaf color or color patterns and have many improved characteristics (plant growth habits, foliage display, tuber sizes and quality, sun tolerance, etc.) that are important for potted and landscape plant production and performance. They are grouped under 8 categories, based on leaf shape and primary colors.

1. This document is ENH 965, one of a series of the Environmental Horticulture Department, Florida Cooperative Extension Service, Institute of Food and Agricultural Sciences, University of Florida. Original publication date September 25, 2003. Reviewed December 9, 2004. Please visit the EDIS web site at http://edis.ifas.ufl.edu.

2. Z. Deng, assistant professor, Gulf Coast Research and Education Center and B.K. Harbaugh, professor, Gulf Coast Research and Education Center, Environmental Horticulture Department, Florida Cooperative Extension Service, IFAS, Univeristy of Florida, Gainesville, 32611.

The Institute of Food and Agricultural Sciences (IFAS) is an Equal Employment Opportunity - Affirmative Action Employer authorized to provide research, educational information and other services only to individuals and institutions that function without regard to race, creed, color, religion, age, disability, sex, sexual orientation, marital status, national origin, political opinions or affiliations. For information on obtaining other extension publications, contact your county Cooperative Extension Service office. Florida Cooperative Extension Service / Institute of Food and Agricultural Sciences / University of Florida / Larry R. Arrington, Interim Dean 


\section{White Fancy-Leaf Type}

Florida Blizzard (Fig. 1) is an attractive addition to the white fancy-leaved cultivar group with its unique foliar color pattern. Florida Moonlight (Fig. 2) represents the first release from the UF breeding efforts in the so-called June Bride type. Both cultivars were bred for forcing in 4- to 8 -inch containers. They produce a superior number of leaves and make attractive pots when buds are excised. In the landscape, they are best grown in partial-sun to shady locations.

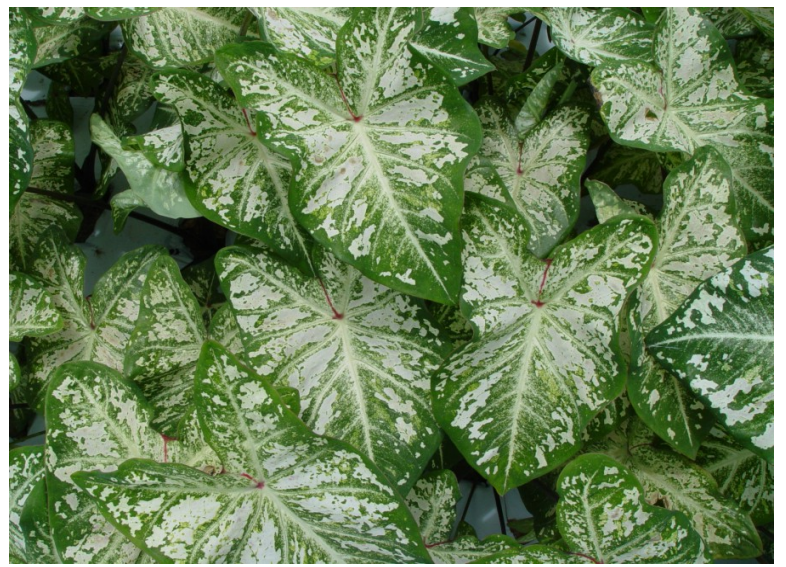

Figure 1. Florida Blizzard

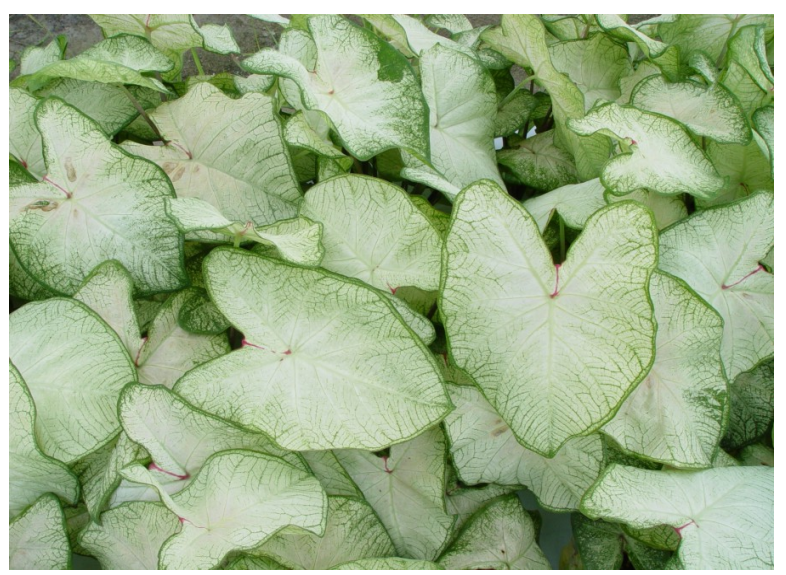

Figure 2. Florida Moonlight

\section{Red Fancy-Leaf Type}

Florida Cardinal (Fig. 3) was bred primarily for forcing in containers. It has a distinctive orange-red color on the surface of tubers.

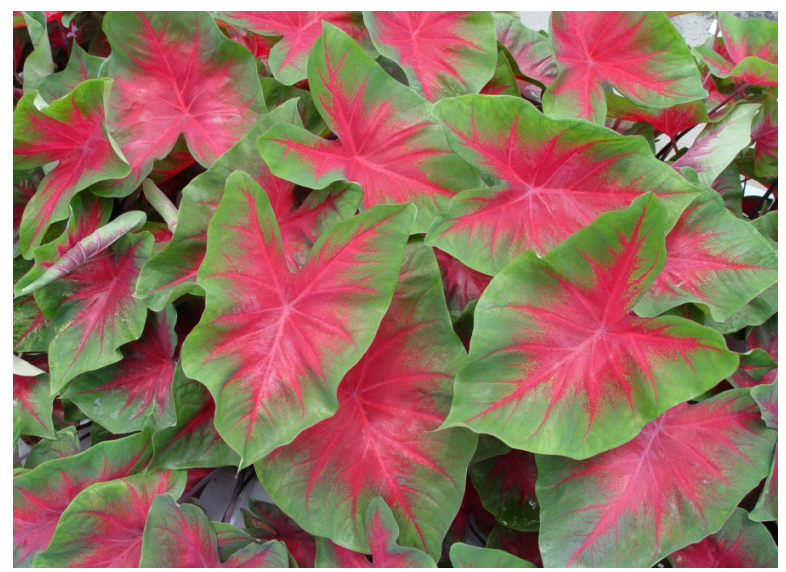

Figure 3. Florida Cardinal

\section{Pink Fancy-Leaf Type}

Florida Roselight (Fig. 4), Florida Elise (Fig. 5), and Florida Calypso (Fig. 6) were bred for primary use in the landscape in sunny or shady locations, but they can also be used for forcing in containers. They have improved sun tolerance over many of the traditional pink cultivars such as Kathleen, and pink leaf colors do not fade to an unappealing tan color when grown without shade.

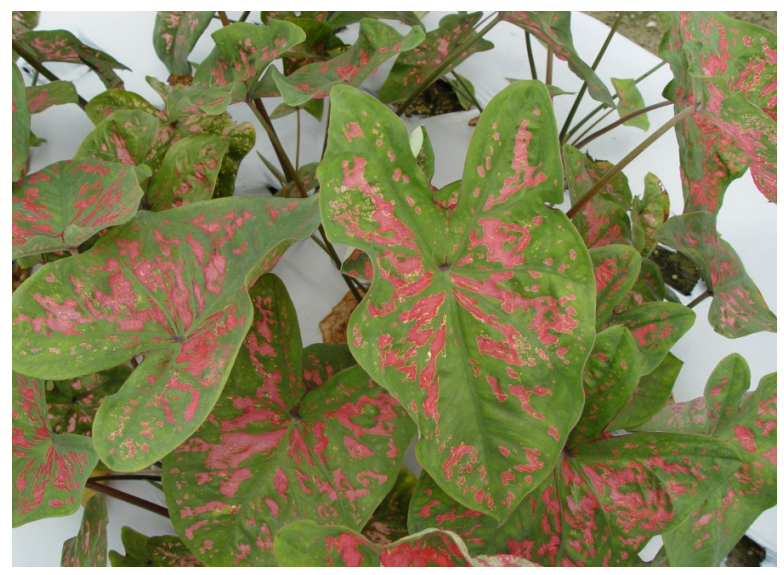

Figure 4. Florida Roselight

\section{Multicolor Fancy-Leaf Type}

Florida Fantasy (Fig. 7) and Florida Sunrise (Fig. 8) show distinct color definitions between the primarily white-faced leaves and the red veins that are rarely found in previous commercial cultivars. They were developed primarily for container production and require de-eyeing for best performance. Shading should be provided in the landscape to avoid possible foliage burning. 


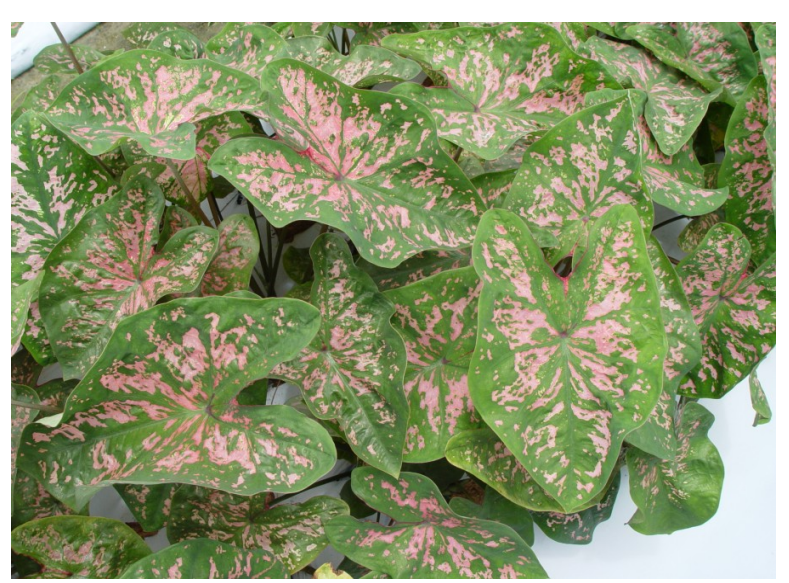

Figure 5. Florida Elise

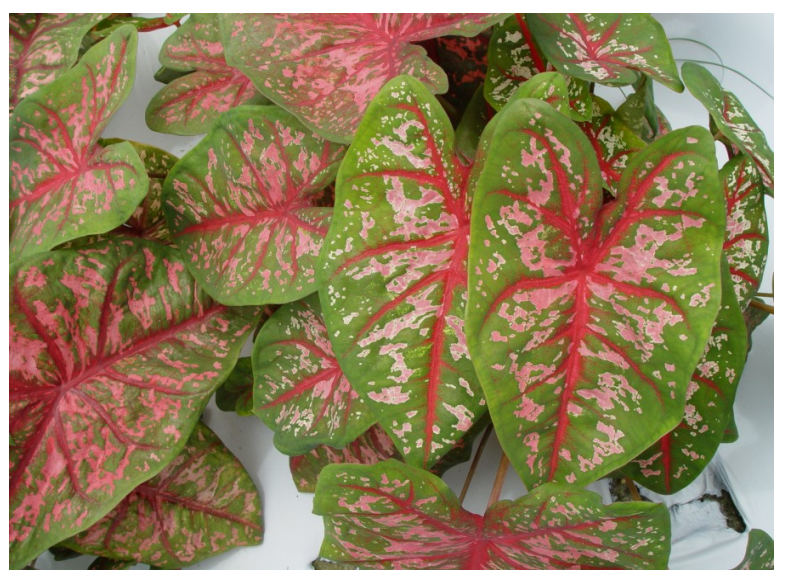

Figure 6. Florida Calypso

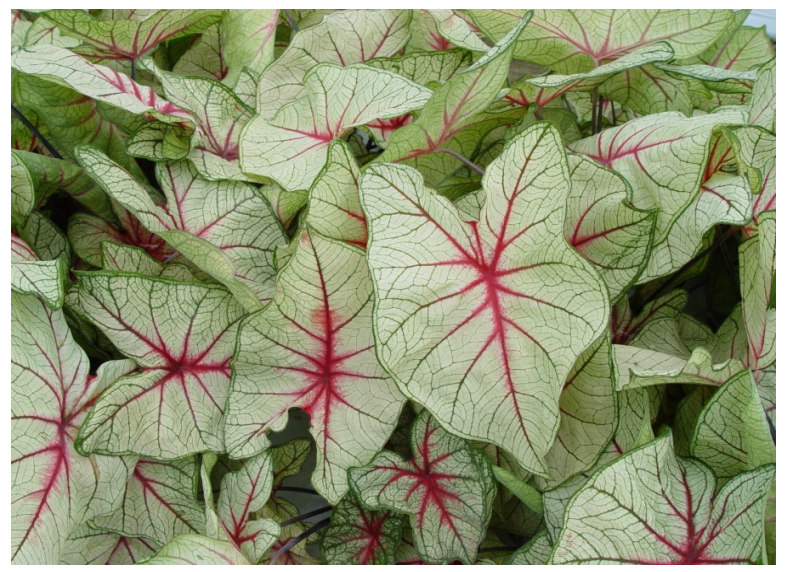

Figure 7. Florida Fantasy

\section{White Lance-Leaf Type}

Florida White Ruffles (Fig. 9) and Florida

Whitewater (Fig. 10) were bred primarily for forcing in containers. They produce highly compact, attractive plants with many leaves and do not require bud excision in forcing.

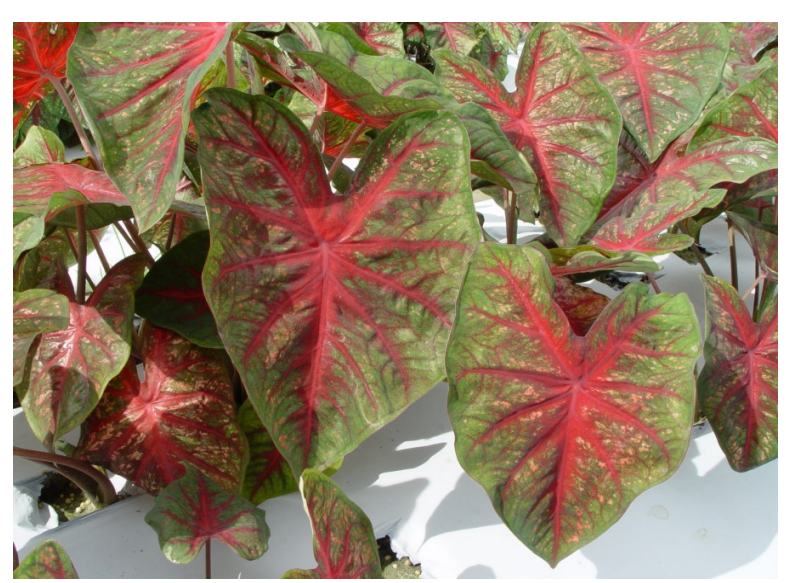

Figure 8. Florida Sunrise

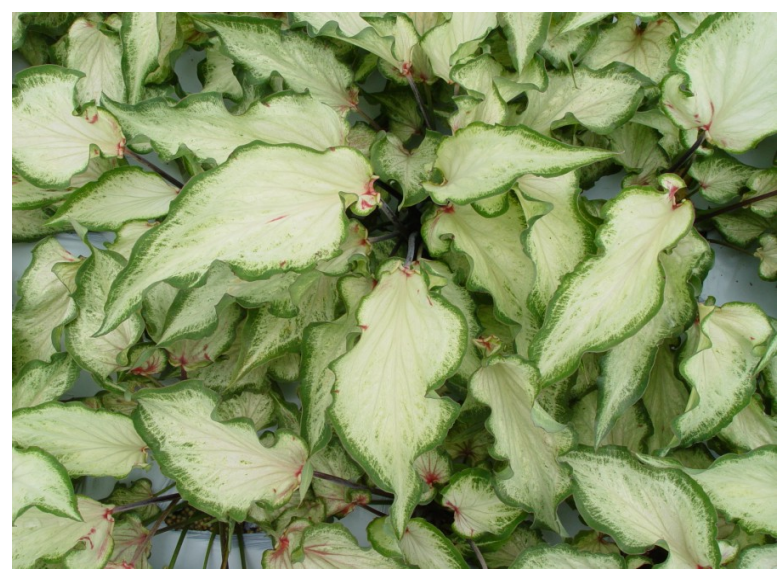

Figure 9. Florida White Ruffles

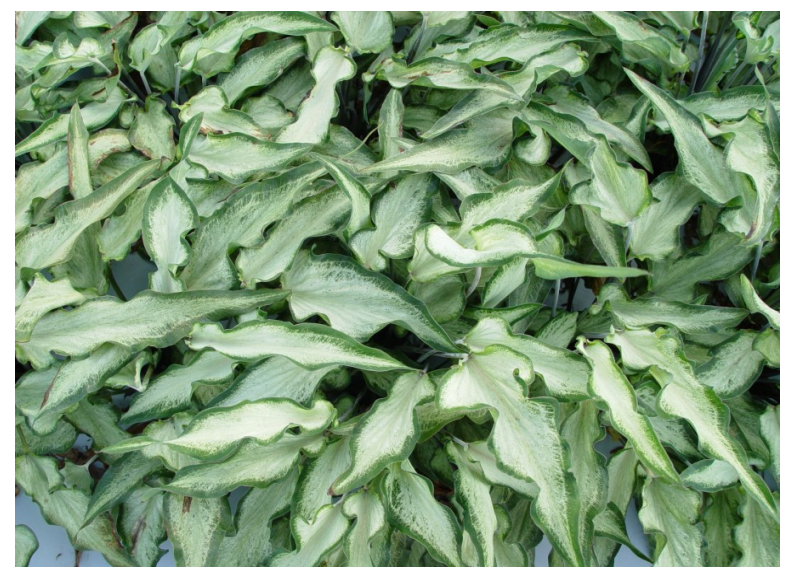

Figure 10. Florida Whitewater

\section{Red Lance-Leaf Type}

Florida Red Ruffles (Fig. 11) is more cold-tolerant than Red Frill and Rosalie, the two major commercial red lance-leaf cultivars. This cold tolerance may help to extend its geographical use in the landscape. 


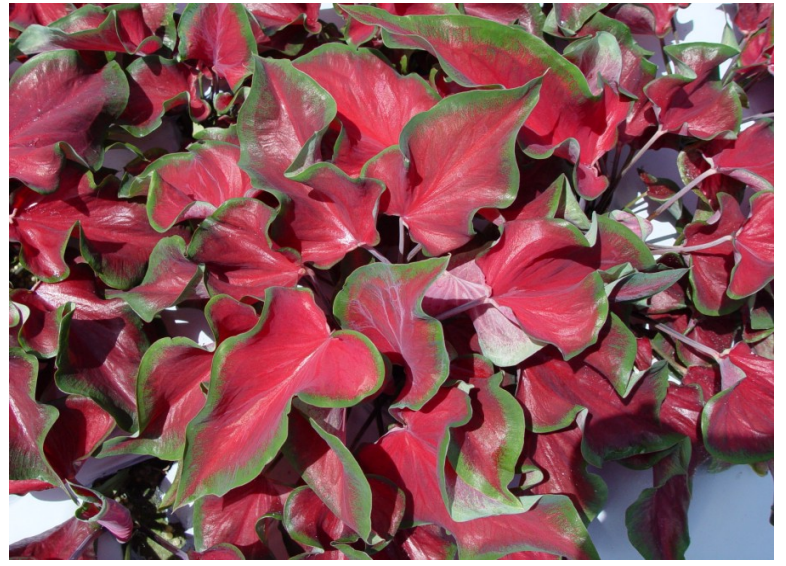

Figure 11. Florida Red Ruffles

\section{Pink Lance-Leaf Type}

Florida Sweetheart (Fig. 12) produces many wide lance leaves with a bright pink color in a unique pattern. It has been the most widely accepted cultivar originating from this breeding program.

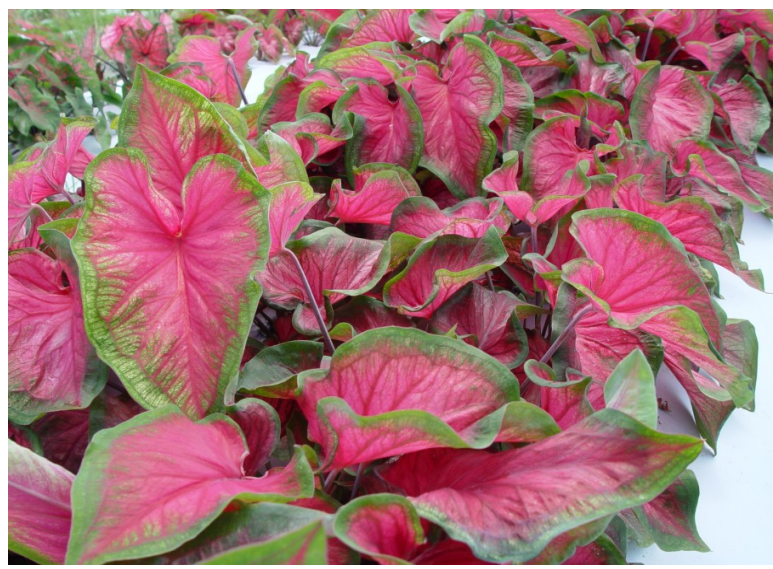

Figure 12. Florida Sweetheart

\section{Green Lance-Leaf Type}

Florida Irish Lace (Fig. 13) produces many long, narrow, green leaves with wavy margins. It is intended for planting tubers directly into the landscape. Plants can be used as a landscape border or in combination with other red or white lance-leaved cultivars.

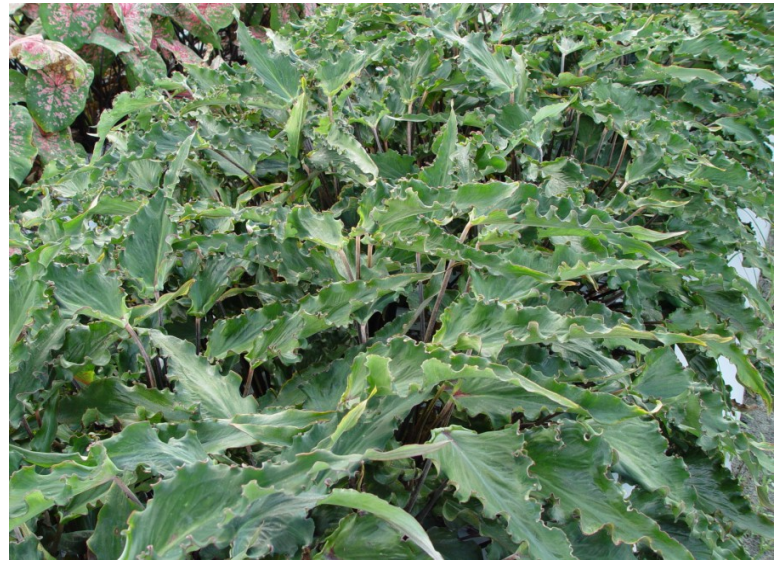

Figure 13. Florida Irish Lace 
Table 1.

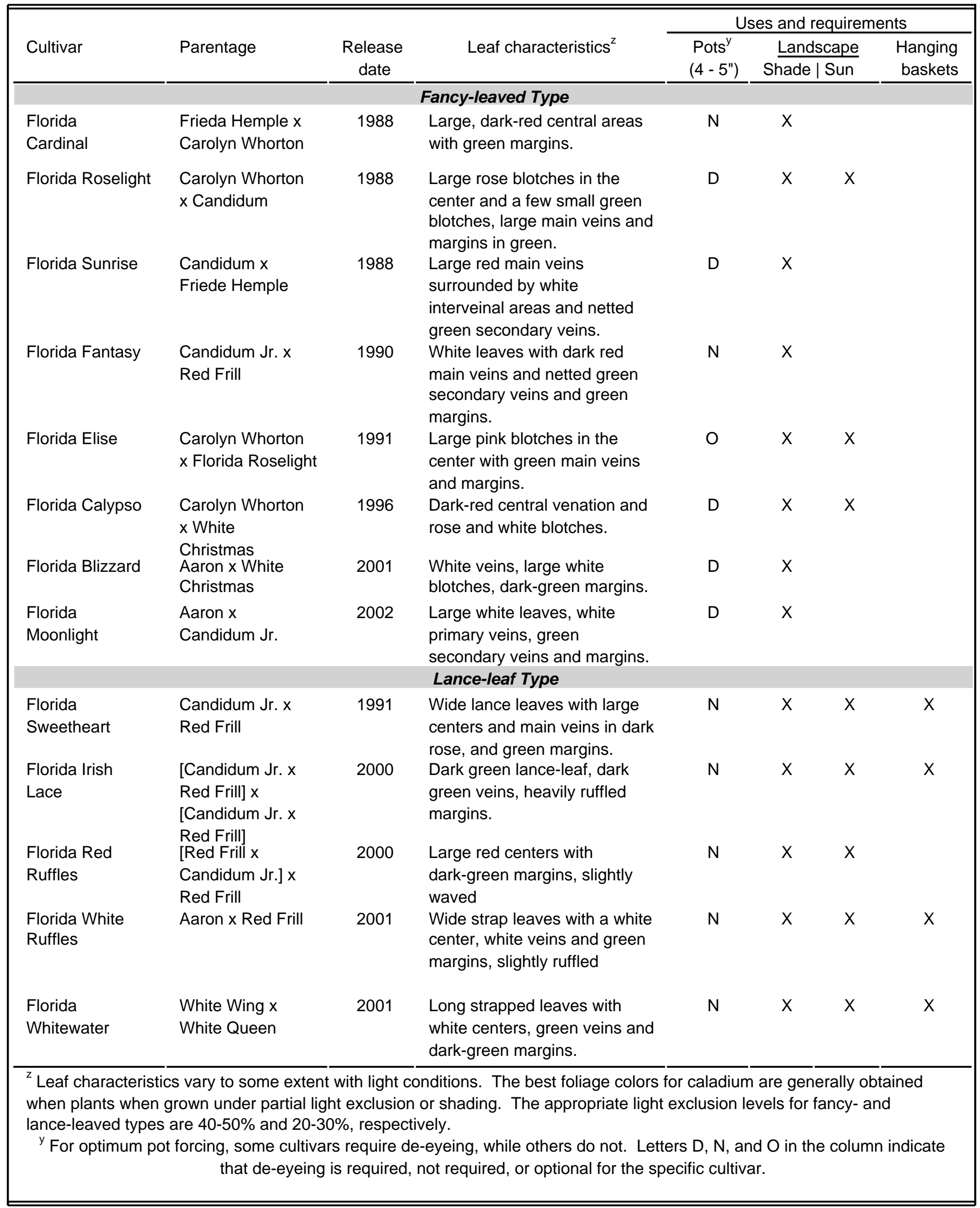

